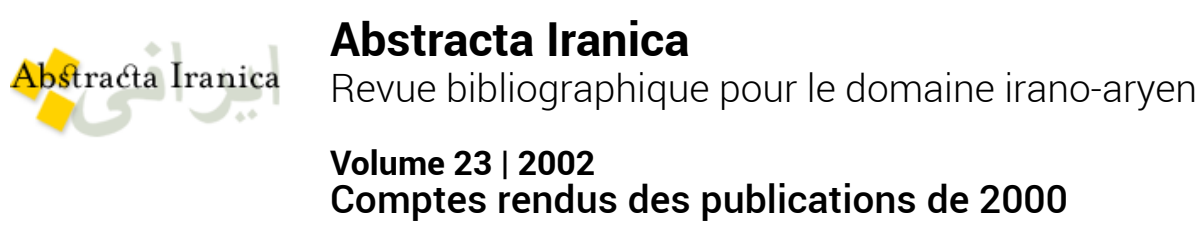

\title{
Terre et cendres. Trad. Sabrina Nouri, Paris, P.O.L., 2000, 93 p.
}

\section{Christophe Balaÿ}

\section{(2) OpenEdition}

1 Journals

Édition électronique

URL : http://journals.openedition.org/abstractairanica/35926

DOI : 10.4000/abstractairanica.35926

ISSN : 1961-960X

Éditeur :

CNRS (UMR 7528 Mondes iraniens et indiens), Éditions de l'IFRI

\section{Édition imprimée}

Date de publication : 15 mai 2002

ISSN : 0240-8910

\section{Référence électronique}

Christophe Balaÿ, «Terre et cendres. Trad. Sabrina Nouri, Paris, P.O.L., 2000, 93 p. », Abstracta Iranica [En ligne], Volume 23 | 2002, document 342, mis en ligne le 08 février 2010, consulté le 25 septembre 2020. URL : http://journals.openedition.org/abstractairanica/35926 ; DOI : https://doi.org/10.4000/ abstractairanica.35926

Ce document a été généré automatiquement le 25 septembre 2020.

Tous droits réservés 


\section{Terre et cendres. Trad. Sabrina Nouri, Paris, P.O.L., 2000, 93 p.}

\section{Christophe Balä̈}

1 Traduction du persan « Khâkestar-e khâk », roman paru aux Éd. Khavaran, Paris, 1999. Cette autre voix persane d'Afghanistan est celle d'un tout jeune romancier vivant à Paris qui décrit l'angoisse d'un vieil homme après le bombardement de sa maison où il a perdu la quasi totalité de sa famille sauf un jeune fils, ouvrier mineur, devant qui il reste impuissant pour exprimer la vérité, sa vérité et celle de tout un peuple. La littérature persane d'Afghanistan, à l'image de la lutte du peuple afghan, est tragique.

INDEX

Thèmes : 11.2. Littérature pashto et dari (Afghanistan)

\section{AUTEURS}

CHRISTOPHE BALA $\ddot{Y}$

IFRI - Téhéran 